\title{
Post-Pandemic Opportunities for Accounting Entrepreneurs in Botswana
}

\author{
Collen Tichaona Mahambo \\ Accounting \& Finance dept. BA ISAGO University \\ Gaborone, Botswana
}

Abstract:- Many businesses have suffered tremendously from the covid-19 pandemic through lost revenues and hence began to downscale. Most changed their business operations from office to remote work by employees. Business performance monitoring activities had not foreseen this global pandemic coming. Therefore, production and deadlines to meet work schedules have been disrupted especially for accounting entrepreneurs whose deadlines are usually imperative day to day discourses. Lockdowns that would come unprepared would drive management and staff in turmoil. These did not only affect internal operations but customers, regulatory bodies and most business stakeholders where in the same boat of reduced functionality. After looking into all these defies, the big question would be whether entrepreneurship would still be able to take advantage of opportunities when the problem is not focused on one country, area, business or sector; but cutting across the globe? Entrepreneurs are seen to be strategic opportunists, especially in times of a crisis like the covid-19 pandemic. In this research, entrepreneurs could be at start-up level, accounting graduates willing to start their own ventures or already functional businesses started by individuals who took the risk to get into their current ventures. Generally, the assumption is that most SMEs (Small-to-medium enterprises) are run by entrepreneurs even though this is not always the case. This research seeks to closely look at the opportunities available to accounting entrepreneurs after going through the challenges of a worldwide pandemic in Botswana. The main aim is to foster entrepreneurship business progressively against the outstanding odds of the covid-19 pandemic. A desktop research was applied to solicit suggestions for not only survival; but a positive forward-looking approach by taking advantage of the current crisis facing all businesses. A qualitative research has been used through journals, publications, discussion and opinion papers in order to explore suggestions for accounting entrepreneurs in the Botswana market. The findings and recommendations showed that accounting entrepreneurial capabilities can be elevated through employment of digital and virtual technologies in their day-to-day businesses and thinking innovatively against current market norms. Businesses therefore are seeking remedies to their financial calamities that have been posed by the covid-19 pandemic. Most "anti-digital" advocates have repented and now appreciate online services even in developing countries like Botswana where many generally shunned or were simply disinterested in digital discourses. The education sector, entertainment, retail and any business that you can think of, have in some way resorted to online alternatives. This combination of impending demand on financial advisory, the rise in appreciation of digital fraternities by all, government support and financing, all pose opportunities post the covid-19 and any other pandemics that may follow. Seetharaman, (2020) articulate how on one hand, the Covid-19 pandemic has imposed huge challenges on business organizations, but on the other hand, it has also compelled for innovations and new opportunities for new business models that will enable them to survive post this current crisis and other future crises.

Keywords:- Accounting, Botswana, covid-19, digital, entrepreneur, financial, pandemic, technology.

\section{INTRODUCTION}

Driven by the coronavirus disease 2019 (COVID-19) that started in Wuhan, China, many countries globally started experiencing unforeseen challenges in business such as mass layoffs of employees, business closures or downsizing and holding investments and transactions to name but a few. This was exacerbated by fear of the unknown; resulting in financially fragile businesses. Some businesses planned to seek funding through the Covid-19 Relief Fund but did not manage and possibly struggled through the bureaucratic hassles and ignorance of establishing eligibility (Bartik et al, 2020). This was further explained by (Donthu \& Gustafsson, 2020) who highlighted how there has been a long history of fear of pandemic outbreaks which resulted in business standstill dilemmas. They interrogated on how we should not focus on just the continued effects of covid-19, but if new outbreaks are to occur again as they tend to recur at $10-50$ year interval, what courses of action should be taken by businesses? People are likely to work remotely, be locked down or restricted in business and movement. However, that does not restrict ideas and the power of imagination on courses of action to take by accounting entrepreneurs. Rather than only taking the protective approach to business such as survival strategies, and masking investments from losses, could there not be new opportunities arising for accounting entrepreneurs. Companies of all sizes are contending with economic and health challenges posed by this pandemic. This study therefore used social cognitive theory as a theoretical framework towards the research of accounting entrepreneurs around the world who got affected negatively through low returns on assets and saving on capital investments which essentially equate to 
distressed economies. This just turns the sequel of balancing economic resuscitation and controlling the pandemic faster as governments struggle save lives and the economy; yet one or both were subsequently left panting for breath. Among other challenges, many entrepreneurs around the world suffered from the recent covid-19 pandemic through the following:

$>$ Closing down businesses

$>$ Downsizing

$>$ Disruption and stifling of business operations

$>$ Closed or restricted borders meant no supplies and no

$>$ No consumption of business products and services

$>$ Reduction in demand

$>$ Employee health concerns

$>$ Behavioral aspects such as

$>$ Saving resources in anticipation of the unknown

$>$ Hoarding or an anticipated change of buyer behavior

$>$ Online shopping and businesses means some middlemen were cut off from business.

\section{THE IMPACT OF COVID-19 ON AFRICAN ECONOMIES}

While covid-19 started affecting China and most western nations, the first case in Africa was only detected in February in Egypt and to date; no African country has been spared. It was generally expected that when the pandemic reaches Africa, the consequences would be worse off than the developed countries that have better technology, medical equipment and other resources to withstand such a calamity. This might have been true in some instances but not all African economies went through the worst cases as was expected. However, it should not be forgotten that most African countries have a wealth of knowledge from dealing with similar epidemics as HIV/AIDS, Ebola and cholera such that they have so much experience in community engagement programmes and communicating the risks to the community towards disease control (United Nations, 2020). As cited in Ryder \& Benefo (2020), the following expectations were predetermined by World Bank Africa's Pulse (2020) which also resonated with IMF (2020) and McKinsey \& Co (2020):

\begin{tabular}{|c|c|c|}
\hline World Bank & McKinsey \& Co & IMF \\
\hline $\begin{array}{c}\text { Average growth to decline from 2.4\% in } \\
2019 \text { to }-2.1 \% \text { to }-5.1 \% \text { in 2020 }\end{array}$ & $\begin{array}{c}\text { Estimated decline in GDP growth from } \\
3.9 \% \text { (initial 2020 GDP growth } \\
\text { forecast) to 0.4\% to -3.9\% }\end{array}$ & $\begin{array}{c}\text { Average growth to decline from 3.1\% in } \\
2019 \text { to }-1.6 \% \text { in } 2020\end{array}$ \\
\hline Could lead to first recession in 25 years & $\begin{array}{c}\text { Possible loss of between } 9 \text { to } 18 \text { million } \\
\text { formal jobs }\end{array}$ & $\begin{array}{c}\text { Risk of unprecedented crisis on weak } \\
\text { healthcare systems }\end{array}$ \\
\hline $\begin{array}{c}\text { African economies could lose between } \\
\text { US \$37-79 billion }\end{array}$ & $\begin{array}{c}\text { About 100 million informal jobs in } \\
\text { vulnerable sectors may be lost }\end{array}$ & $\begin{array}{c}\text { Virus control measures are causing economic } \\
\text { crisis and making daily life difficult for the } \\
\text { already vulnerable groups }\end{array}$ \\
\hline $\begin{array}{c}\text { Probability of severe food crisis, with a } \\
2.6 \% \text { to 7\% decline in agricultural } \\
\text { production }\end{array}$ & & $\begin{array}{c}\text { A decrease in flow of external investment } \\
\text { from partners outside Africa }\end{array}$ \\
\hline
\end{tabular}

Table 1:- Expected Impact of covid-19 on Africa

Source: WB Africa's Pulse (2020); McKinsey \& Co (2020) \& IMF (A2020) as cited in Ryder \& Benefo (2020)

Most African countries have suffered heavy decline in economic growth in line with the above foresights. The expected decrease in the Gross Domestic Product (GDP), will negatively affect African economies especially as most were already suffering in terms of weakened currencies, unemployment, other epidemics like Ebola and HIV/AIDS including thecovid-19 pandemic. Against this backdrop, some African countries have taken aggressive measures to simultaneously protect both their economies and the health of their citizens. See the extract below from UNDP (2020)'s survey:

Economic responses by African countries against covid-19

\begin{tabular}{|c|c|c|c|}
\hline Response & SME Support & Social Programs & Income Support \\
\hline No. of countries & 22 & 20 & 18 \\
\hline \multicolumn{4}{|c|}{ Macro-economic responses } \\
\hline Response & Exchange rate & Monetary policy & Fiscal policy \\
\hline No. of countries & 4 & 37 & 44 \\
\hline
\end{tabular}

Table 2:- African and Macro-Economic Responses

Out of the 54 countries in Africa, the UNDP (2020) analysis showed only $41 \%$ of the African countries gave Small-to-Medium Enterprise (SME) support, 37\% had social programs and only $33 \%$ were giving income support to their businesses. The exchange rate had a negligible response used towards the covid-19 pandemic by the African countries whereas the majority of $68 \%$ to $82 \%$ were applying monetary and fiscal policies towards resuscitating their economies from the covid-19 impact and not manage to support businesses and offer social programs assistance. 
This clearly shows that most countries in Africa generally struggled to give the much needed support for the business environment except for the businesses to largely depend on the monetary and fiscal policies of their governments. Therefore, those countries which went a step further to support SMEs or provide some helpful social programs were minimal. Economic depletions predicted by WB Africa's Pulse (2020); McKinsey \& Co (2020) \& IMF (A2020) as cited in Ryder \& Benefo (2020) above would become highly probable.

\section{IMPACT OF COVID-19 ON BOTSWANA'S BUSINESS ENVIRONMENT}

Botswana has not been spared in the above problems. After realizing its first case on 30 March 2020, Botswana still has some of the lowest cases in the world and in Africa. From realizing a strong economic growth of $4.5 \%$ in 2018 , economic growth is estimated to have slowed down to $3.5 \%$ in 2019 which just shows the effects of weakened global demand for diamonds alongside severe droughts affecting the region (World Bank, 2020). This was further worsened by the covid-19 in the period 2019/2020. Trade restrictions with Botswana's major suppliers especially from South Africa have also contributed to the slowdown in business. During the era of the covid-19 whirlwind, the Botswana Government applied the, "people first" approach, with strict adherence of covid-19 measures across the country and the economic recovery following behind. They were generally following the five pillars of the UN framework suggested for combating covid-19 which are as follows:

1. Health first - protecting health services and systems during a crisis

2. Protecting people - social protection and ensuring basic services

3. Economic recovery - protecting jobs, SMEs and the most vulnerable and productive actors

4. Macroeconomic response and multilateral collaboration macroeconomic response and multilateral collaboration; and

5. Social cohesion and community resilience - social cohesion and community resilience.

\section{Source: United Nations (2020)}

These steps where very much instrumental in keeping reasonable stability in the economy with manageable corona virus cases in the country to date. Botswana accounting entrepreneurs have not been scathed by the effects of the covid 19, and also are part of the Botswana government's responses and initiatives towards economic diversity and growth. The above covid-19 encounters challenged their clients, who are the wide business communities who are unaware of what to do with their investments and businesses that have taken in the shocks of the covid-19 pandemic. Looking to China and other countries who quickly recovered and turned the covid-19 crisis into opportunities, Botswana's accounting entrepreneurs could learn a lot and help to revive the economy. Other countries in the region could be expected to learn from Botswana hence accounting entrepreneurs in Botswana have immense contributions to turning around the current dogma caused by covid19. Davis (2019) resonated with Ntakhwana (2017) as she was relating to former BICA's Chief Executive Officer, who explained the role of accountants or Botswana Institute of Chartered Accountants (BICA) members as an advisory role towards implementing management reforms.

\section{RESEARCH METHOD}

In view of the new opportunities available for accounting entrepreneurs, this study used desktop research by examining specific applicable research documents from UN, World Bank, the Botswana government, and other literature. Some website articles, journals, and other online sources were reviewed. In line with the prevailing covid-19 consequences, also reviewed were literatures from some unpublished articles which were giving sensible and relevant information to the study. Most of the literature used was from 2019 onwards in order to give recent suggestions for the accounting entrepreneurs in Botswana. Articles being selected followed key titles and terms which were closely related to the study. This included key phrases such as, 'accounting entrepreneurs', 'opportunities available to entrepreneurs', 'post covid-19 entrepreneurship opportunities', 'China's lessons from covid-19', among others. Examined and reviewed were key deliverables and results from these studies. 32 articles were examined which also included local newspaper articles from Botswana and neighboring countries like South Africa and Namibia if they were relevant to the topic. From the selected articles, judgmental selection was done on the pool of articles found in order to be purposive to the specifically required information for this study. Thorough analysis and research has been compiled in these papers including statistical references to the covid impact, graphs, charts and other pictorial analysis from credible sources such as UN, World Bank and the Botswana Government publications. These were instrumental in drawing formidable evidence to the opportunities available to Botswana's accounting entrepreneurs.

\section{LITERATURE REVIEW}

Having seen the predicament of high unemployment among accounting graduates in Nigeria, Odia, \& Odia,(2013), suggested the need for accounting graduates to be entrepreneurial and turn the current challenges in the economy of Nigeria into business opportunities. They reckoned how some time back, companies used to be the ones chasing accounting graduates while still at university, yet today, experience has erected an unimaginable barrier which has further escalated the graduates' unemployment rate. The covid-19 crisis further exacerbates the unemployment plight for accounting graduates, especially with companies closing down, down-sizing or otherwise. Entrepreneurship has to be on the top-list of Botswana's accounting graduates and education curriculum if the current pandemic, unemployment and any other possible future crisis are to be won over towards reviving Botswana's economy. To face it head-on, being in a crisis like the current pandemic on one side of the coin is a 
challenge, but on the other there is a significant opportunity that businesses really need accounting advisory services. In their paper, "Startups in times of crisis-A rapid response to theCOVID-19 pandemic",Kuckertz et al (2020) did not only see the pandemic as a barricade to entrepreneurial initiatives but possibilities for remedying the consequences of this pandemic and other crisis. This is similar to defending by attacking which works well not only in a game of chase, football or other sports, but such crisis as this pandemic. If the accounting entrepreneurs in Botswana are to survive economic meltdown against ulterior expectations, they have to see this covid era as an opportunity. In such a time as the appalling financial crisis caused by the most horrible current pandemic, organizations need strong leadership from finance professionals to set a reassuring air and outline the best course of action to overcome their fears (Butcher, 2020). This shows how accounting services are much needed during and post the covid-19 pandemic, and accounting entrepreneurs in Botswana have to open their eyes to this treasurable opportunity. Sneader and Singal (2020) also reiterated that the coronavirus is not just a huge health crisis in the whole world, but it is also an impending universal restructuring towards a new world order which will follow the five steps below:

\section{Resolve $\rightarrow$ Resilience $\rightarrow$ Return $\rightarrow$ Reimagination $\rightarrow$ Reform.}

Therefore, accounting entrepreneurs in Botswana not only need to be deeply immersed in the worries and economic impediments of covid-19, but to quickly reimagine Botswana businesses post covid-19 and innovate towards the forthcoming new world order in accounting service deliveries. The accounting entrepreneurs themselves should similarly reimagine new ways of delivering their services. They could possibly resurface new accounting reforms for the Botswana market. Entrepreneurs have a significant resolution to the economy of the country and against unemployment.

\section{A. Services and opportunities available specifically for accounting entrepreneurs}

Davis (2019) and advised accounting and auditing entrepreneurs in 2020 and beyond to look into the following top accounting business ideas:

$>$ Financial Data Management

$>$ Financial Management

$>$ Financial Report Preparation

$>$ Analysis And Advice

$>$ Regulatory and Reporting Compliance

$>$ External Business Affiliations

$>$ Bookkeeping

$>$ Auditing

$>$ Risk analysis

$>$ Due diligence

$>$ Business Strategy

$>$ Investment strategies and guidance

$>$ Budgeting, forecasting and cash flow projections
ACCA (2020) warned that "the corporate graveyard is full of businesses that took their eye of the finances". With the current crisis, companies; especially SMMEs really need the above accounting services but at an affordable price.

\section{B. Why accounting Entrepreneurs?}

Arnold (2020) perceived that in a crisis, small businesses need small accounting firms. This is true as the small businesses do want accounting services but usually they cannot afford the prices that are charged by bigger accounting firms. However, he went on to make the following supporting reasons:

$>$ SMMEs in this challenge need accountants they can closely trust and easily relate to like SMAPs (Small and Mid-sized Accounting Practices) who understand the reality of being a small player.

$>$ with the crisis at hand, empathy is in high demand and hence they need accountants who do not just do books, tax, audits and conventional accounting services, but more than that.

$>$ SMAPs can provide tailored and real-time guidance to entrepreneurs' companies as many changes are taking place within many businesses

Government of Botswana (2020) has disposed so much support for businesses that the accounting entrepreneurs can take to their advantage of this support and foster their own businesses forward in line with the Government's mandate to resuscitate the economy.

Accounting services are highly needed to boost companies out of the challenges they are facing. Delalio (2020) encouraged businesses to pivot their accounting operations differently towards combating covid-19 influences.

\section{Availability of entrepreneurship support financial institutions}

Besides the opportunity of increasing demand for accounting services, another opportunity that has arisen for accounting entrepreneurs in Botswana is the presence of robust entrepreneurial supporting agencies in Botswana. In moving away from Official Development Assistance (ODA) when the country was declared a middle income economy, Calleja, \& Prizzon, (2019) showed how the government of Botswana is pursuing its National Devepment Plans depict how Botswana set up financial institutions that are there to financial entrepreneurial skills and businesses. Previously, when Botswana was among the lower income countries, donors would finance institutions, businesses and other ventures. Mahambo, Chiguvi and Lynch (2016) mentioned the problem with donors that when they finance, they may dictate how the funds are used and are volatile in their funding; depending on new issues that need funding. As such, nurturing of entrepreneurial skills would most likely be demented. Important lessons could be learnt from how Botswana migrated from donor-dependency to setting up local institutions to fund businesses and entrepreneurial skills. Ama \& Okurut (2018) and Kuruba \& Gilika (2014).mentioned such institutions as LEA (Local Enterprise Authority), CEDA (Citizen Entrepreneurial 
Development Agency) and YDF (Youth Development Fund). These institutions are capable of pouring in funds to viable businesses and entrepreneurs towards empowering Botswana citizens. This shows that there are structures and systems in Botswana that strongly support entrepreneurship. During the time of the pandemic, the President of Botswana addressed the nation towards the launching of the revised CEDA Guidelines (Masisi, 2020). He went on to encourage the youth that the revised CEDA Guidelines were meant to equip citizens with entrepreneurial and management skills especially during this covid-19 period. Even encouraging was the flexibility that the guidelines brought with them:

$>$ Loan limits were increased substantially

$>$ Interest rate for loans for SMEs were tremendously reduced

$>$ Favourable collateral terms for businesses borrowing loans from CEDA in respective business sectors

All these business initiatives that would respond to such a convivial call would require accounting services from an accounting entrepreneur. At the same time, the accounting entrepreneurs themselves could also apply for the CEDA funding invitation.

\section{Technological advancements in Botswana}

According to Lapinskien (2020), the recent pandemic has accelerated the need to transform the finance function using technological innovations. Conventional ways of accounting are quickly being replaced by innovative digital skills and entrepreneurial skills are required to bring about this change. Botswana recognises technology and innovation as one critical sector that it is investing in seriously. Delalio (2020) recommended technological initiatives as the best methods to combat accounting services during and post the covid-19 pandemic. The Botswana government has taken great strides and initiatives in promoting technology and innovation by businesses and its citizens. The Botswana Household Access \& Individual Use of Information \& Communication Technologies reports that have been held consecutively by Botswana cannot go unnoticed as it hows the seriousness with which the government is taking towards improving ICT systems, policies and infrastructure for its businesses and citizens (Statistics Botswana, 2020). They revealed increasing statistics of the use of technology among individuals in Botswana which is good for ICT-based solutions by accounting entrepreneurs in this era. The establishment of BoFiNet (Botswana Fiber Networks) entity was meant to reshape the technological industry of Botswana by providing unprecedented internet connectivity and worldclass network connectivity. To date, BoFiNet is working on the Fibre To The Home (FTTH) project which is meant to install optical Fibre to individual buildings for very fast internet connectivity (BOFINET, 2020). These and other related projects are setting up a very good foundation and support for Botswana's accounting entrepreneurs pre- and post the covid-19 pandemic.

\section{ANALYSIS AND RESEARCH FINDINGS}

Government and international organisations such as IMF and World Bank's publications have been used in collating data with literature in order to give an analysis of the research. This will help to produce findings for opportunities available to accounting entrepreneurs after the covid-19 pandemic. Expectations from IMF showed an expected global economic decline by $3 \%$ while that of Africa is expected to be just above the global decline as shown in Table 1. However, Botswana's decline will be expected to be better than most of its African counterparts at a reasonable decline of $2 \%$ (BITC, 2020). This is because of the stringent measures that Botswana put in place and has been ranked within the top 10 best responders to the economic challenges that have been posed by covid19. Such initiatives and covid-19 proposed interventions by the Government towards upholding the economy as given below:

\begin{tabular}{|c|c|c|c|c|}
\hline & Intervention & Objectives & Conditions & $\begin{array}{l}\text { Benefit to accounting } \\
\text { entrepreneurs }\end{array}$ \\
\hline 1 & $\begin{array}{l}\text { The wage } \\
\text { subsidy to } \\
\text { companies }\end{array}$ & $\begin{array}{l}\text { This was meant to support } \\
\text { eligible businesses affected by } \\
\text { COVID-19 to maintain their } \\
\text { staff complement against } \\
\text { retrenchments, and } \\
\text { simultaneously enabling } \\
\text { employees to have income } \\
\text { during the lockdown period or } \\
\text { when operating at below } \\
\text { normal working capacity. }\end{array}$ & $\begin{array}{l}\text { - 50\% Subsidy of basic salary } \\
\text { for citizen employees or } \\
\text { - Minimum subsidy of } \\
\text { P1000/month and maximum } \\
\text { of P2500/month Pay to } \\
\text { businesses that qualified for } \\
\text { the subsidy but contingent } \\
\text { upon no retrenchments, still } \\
\text { pay salaries even for } \\
\text { temporarily laid off staff. }\end{array}$ & $\begin{array}{l}\text { - Their own enterprises could } \\
\text { continue operating. Staff could } \\
\text { operate from home while } \\
\text { guaranteed of receiving pay } \\
\text { - Accounting entrepreneurs } \\
\text { would still do books and other } \\
\text { duties for their clients } \\
\text { including payroll processing } \\
\text { and receive revenues }\end{array}$ \\
\hline 2 & Loan guarantee & $\begin{array}{l}\text { There would still be access to } \\
\text { credit facilities by the } \\
\text { government so that business } \\
\text { operations would continue } \\
\text { against increased risks imposed } \\
\text { by covid-19 }\end{array}$ & $\begin{array}{l}\text { - No guarantee fee with a } 24 \\
\text { months guarantee period } \\
\text { - Borrower to be ineligible } \\
\text { sector }\end{array}$ & $\begin{array}{l}\text { - Assist clients with credit } \\
\text { facility processing } \\
\text { advisory services }\end{array}$ \\
\hline
\end{tabular}


ISSN No:-2456-2165

\begin{tabular}{|c|c|c|c|c|c|}
\hline 3 & $\begin{array}{l}\text { Support by } \\
\text { government } \\
\text { agencies }\end{array}$ & $\begin{array}{c}\text { CEDA supported SMEs to } \\
\text { restructure loans waiving } \\
\text { interest payments for } 12 \text { months } \\
\text { Packages following same core } \\
\text { principles } \\
\text { BITC three to six months rental } \\
\text { deferral for tenants in our } \\
\text { factory shells }\end{array}$ & None & $\begin{array}{l}\text { - Advisory } \\
\text { preparation } \\
\text { financials }\end{array}$ & $\begin{array}{cr}\text { services } & \text { and } \\
\text { of } & \text { required }\end{array}$ \\
\hline
\end{tabular}

Table 3:- Proposed Government Interventions against covid-19 economic impact Source: (BITC, 2020)

The findings from the above table showed that accounting entrepreneurs' services are highly needed during a time like this. From the research, literature is also supporting the need for digitalizing accounting services towards assisting businesses facing a pandemic like covid19. While the business environment seems blurry and conspicuous, with investors cautious to disburse or move capital, it is an opportune moment for accountants to intervene and advise business on the way forward, especially post the current harsh economic climate caused by the pandemic. With immense government support as shown in table 3 to both the SMEs the accountants serve and their own accounting practices, the following opportunities were realised from this research:

$>$ Opportunity to get government funding to transform accounting entrepreneurs' practices into digital hubs for accounting services

$>$ The opportunity to do businesses seeing as most SMEs are most likely to be seeking accounting services towards revamping their businesses

$>$ Growth opportunities through global reach as online financial services will allow them to offer services across borders

Ability to create new partnerships

$>$ The entrepreneurs could better compete with established accounting firms but in their own niche of serving fellow smaller firms who usually cannot afford the fees charged by bigger firms.

$>$ Savings will be made through wider market coverage yet with modest investments from cloud computing, fewer asset investments and the ability to do business flexibly

$>$ The opportunity to innovate and come up with new ways of doing business especially in thi current age where people have accepted the effectiveness of digital technology.

\section{CONCLUSION AND RECOMMENDATIONS}

Agreeably, it may still be too early to predict the impact of covid-19 in Botswana with the accounting entrepreneurs on one hand face some risks and challenges, but on the other, opportunities disguised in the present challenges. Risks of competition from bigger accounting firms, lack of appropriate certification to run their businesses, ignorance in digital competitiveness and innovativeness and principally, the ordinary health risks that are caused by the covid-19 pandemic. However, Botswana government's support structures and the inherent need for accounting services and advice, do open doors of opportunities for Botswana's SMEs. Many countries in Africa could not afford their entrepreneurs and businesses the government support that has been rendered Botswana's entrepreneurs' community. With funding agencies ready to support entrepreneurs' competitiveness locally and across the globe, convenient opportunities lie ahead post the current covid-19 pandemic. Botswana's accounting entrepreneurs ought to be innovative and tailor business models and systems that incorporate digital facilities to enable them to meet their customers' needs post this and any other pandemic.

\section{REFERENCES}

[1]. Ama, N. O., \& Okurut, F. N. (2018). Micro, Small, and Medium-Sized Enterprises (MSMEs) and Open Collaborative Innovation in Botswana (Vol. 15). Working Paper.

[2]. Arnold, C., 2020. In Crisis, Small Businesses Need Small Accounting Firms. [online] Accounting Today. Available at: $<$ https://www.accountingtoday.com/opinion/smallbusinesses-are-struggling-heres-how-accountants-canbe-trusted-partners-during-this-crisis> [Accessed 19 August 2020].

[3]. Bartik, A. W., Bertrand, M., Cullen, Z., Glaeser, E. L., Luca, M., \& Stanton, C. (2020). The impact of COVID-19 on small business outcomes and expectations. Proceedings of the National Academy of Sciences, 117(30), 17656-17666.

[4]. BOFINET, 2020. Bofinet Launches Fibre To The Home Project | Bofinet. [online] BoFiNet. Available at:

<https://www.bofinet.co.bw/news/article.php?a=1\&art icle $=$ BoFiNet $\% 20$ Launches $\% 20$ Fibre $\% 20$ to $\% 20$ the $\%$ 20Home\%20Project\#> [Accessed 22 August 2020].

[5]. Butcher, D. (2020). CFOs RESPOND TO THE COVID-19 PANDEMIC. Strategic Finance, 101(11), 24-31.

[6]. Butcher, D. (2020). CFOs RESPOND TO THE COVID-19 PANDEMIC. Strategic Finance, 101(11), 24-31.

[7]. Davis, S., 2019. What Role Does An Accountant Play In Business Operations?. [online] Small Business Chron.com. Available at: $<$ https://smallbusiness.chron.com/role-accountantplay-business-operations-411.html> [Accessed 18 August 2020]. 
[8]. Delalio, J., 2020. How To Pivot Your Accounting Operations: Coping With COVID-19. [online] EisnerAmper. Available at: $<$ https://www.eisneramper.com/covid-19-accountingoperations-0320/> [Accessed 21 August 2020].

[9]. Donthu, N., \& Gustafsson, A. (2020). Effects of COVID-19 on business and research. Journal of Business Research, 117, 284.

[10]. Government of Botswana, 2020. Covid-19 Assistance For Businesses. [online] Government of Botswana. Available at: <https://covid19portal.gov.bw/assistance-businesses> [Accessed 21 August 2020].

[11]. Government of Botswana, 2020. Covid-19 Assistance For Businesses. [online] Government of Botswana. Available at: <https://covid19portal.gov.bw/assistance-businesses> [Accessed 21 August 2020].

[12]. Kuckertz, A., Brändle, L., Gaudig, A., Hinderer, S., Reyes, C. A. M., Prochotta, A., ... \& Berger, E. S. (2020). Startups in times of crisis-A rapid response to the COVID-19 pandemic. Journal of Business Venturing Insights, e00169.

[13]. Lapinskiene, V. (2020). Lessons learnt from COVID19: Building a resilient finance function. International Tax Review.

[14]. Mahambo, C., Chiguvi, D., \& Lynch, N. (2016). The Sustainability of donor-funding towards nongovernmental organisations and their socio-economic impact in Botswana.

[15]. Masisi, E.K., 2020. LAUNCH OF THE REVISED CEDA GUIDELINES.

[16]. Ntakhwana, O., 2017. MoU to enhance capacity of public accountants. Botswana Daily News, [online] p.1. Available at: $<$ http://www.dailynews.gov.bw/mobile/newsdetails.php?nid=37806\&flag $=>$ [Accessed 18 August 2020].

[17]. Odia, J. O., \& Odia, A. A. (2013). Developing entrepreneurial skills and transforming challenges into opportunities in Nigeria. Journal of Educational and Social Research, 3(3), 289-289.

[18]. Ryder, H. W., \& Benefo, A. (2020). COVID-19: Impacts on African economies-economic challenges and social safety net responses.

[19]. Sneader, K., \& Singhal, S. (2020). Beyond coronavirus: The path to the next normal. McKinsey \& Company.

[20]. United Nations, 2020. A UN Framework For The Immediate Socio-Economic Response To COVID-19. [online] Un.org. Available at: <https://www.un.org/sites/un2.un.org/files/un_framew ork_report_on_covid-19.pdf> [Accessed 20 August 2020].

[21]. United Nations, 2020. Policy Brief: Impact Of COVID-19 In Africa. [online] Uneca.org. Available at: $<$ https://www.uneca.org/sites/default/files/Publication Files/sg_policy_brief_on_covid19_impact_on_africa_may_2020.pdf> [Accessed 18 August 2020].
[22]. World Bank, 2020. Overview. [online] World Bank. Available at: <https://www.worldbank.org/en/country/botswana/ov erview> [Accessed 20 August 2020]. 